\title{
Breaking Down and Building Up: Gentrification, Its drivers, and Urban Health Inequality
}

\author{
Helen V. S. Cole ${ }^{1}$ (D) Roshanak Mehdipanah ${ }^{2} \cdot$ Pedro Gullón $^{3} \cdot$ Margarita Triguero-Mas $^{1}$
}

Accepted: 3 March 2021 / Published online: 13 March 2021

(C) The Author(s), under exclusive licence to Springer Nature Switzerland AG 2021

\begin{abstract}
Purpose of Review Many neighborhoods which have been unjustly impacted by histories of uneven urban development, resulting in socioeconomic and racial segregation, are now at risk for gentrification. As urban renewal projects lead to improvements in the long-neglected built environments of such neighborhoods, accompanying gentrification processes may lead to the displacement of or exclusion of underprivileged residents from benefiting from new amenities and improvements. In addition, gentrification processes may be instigated by various drivers. We aimed to discuss the implications of specific types of gentrification, by driver, for health equity.

Recent Findings Several recent articles find differential effects of gentrification on the health of underprivileged residents of gentrifying neighborhoods compared to those with greater privilege (where sociodemographic dimensions such as race or socioeconomic status are used as a proxy for privilege). Generally, studies show that gentrification may be beneficial for the health of more privileged residents while harming or not benefiting the health of underprivileged residents. Very recent articles have begun to test hypothesized pathways by which urban renewal indicators, gentrification, and health equity are linked. Few public health articles to date are designed to detect distinct impacts of specific drivers of gentrification.

Summary Using a case example, we hypothesize how distinct drivers of gentrification - specifically, retail gentrification, environmental gentrification, climate gentrification, studentification, tourism gentrification, and health care gentrification-may imply specific pathways toward reduced health equity. Finally, we discuss the challenges faced by researchers in assessing the health impacts of gentrification.
\end{abstract}

Keywords Health equity · Gentrification · Urban renewal · Studentification · Touristification · Urban health

This article is part of Topical Collection on Built Environment and Health

Helen V. S. Cole

Helen.cole@uab.cat

Roshanak Mehdipanah

rmehdipa@umich.edu

Pedro Gullón

pedro.gullon@uah.es

Margarita Triguero-Mas

mtrigueromas@gmail.com
1 Barcelona Lab for Urban Environmental Justice and Sustainability (BCNUEJ), Institute of Environmental Science and Technology (ICTA), Autonomous University of Barcelona (UAB) and the Medical Research Institute of the Hospital del Mar (IMIM), C/ Doctor Aiguader, 88, 08003 Barcelona, Spain

2 School of Public Health, University of Michigan, Ann Arbor, USA

3 Public Health and Epidemiology Research Group, Universidad de Alcalá, Alcalá de Henares, Spain 


\section{Introduction}

\section{Urban Health Inequity}

Urban social (e.g., economic factors, educational opportunities, and employment conditions) and physical (e.g., transportation infrastructure, housing quality, and food access) inequalities have important implications for health. These urban inequalities are further exacerbated discrimination, limiting opportunities and creating unjust exposures based on one's race or ethnicity, age, gender, and/or sexuality $[1,2]$. For example, in the USA, residential segregation, based on historical discriminatory housing policies, has resulted in and maintains a situation in which more Black and Latinx residents live in under-resourced neighborhoods [3, 4]. These neighborhoods have limited access to resources such as healthy foods and good-quality schools, and are more likely to have concentrated poverty and to experience high crime rates $[5,6]$. These inequities have been linked to an array of health outcomes including obesity [7], breast cancer [8], asthma [9], and mortality [10].

Urban social and physical inequalities are also linked to unequal environmental exposures. The resulting environmental injustices, defined as the unjust distribution of unhealthy environments such as exposure to toxic waste, air and water pollution, and/or unhealthy working and living conditions, disproportionately affect neighborhoods with higher rates of poverty and/or racial and ethnic minority residents, who are more likely to live in areas with poorer environmental conditions [11, 12]. These differential and unjust environmental exposures are linked to contrasting health outcomes like pregnancy outcomes, childhood cancer, and cardiovascular and respiratory illnesses [13-16]. Thus, instances of health inequity, or avoidable and unjust differences in health outcomes [2], are often a result of differences in environmental conditions, unevenly distributed within urban areas. For example, social factors such as the impacts of interpersonal and institutional racism - that contribute to worse health outcomes among minority urban residents $[5,17]$-also contribute to the persistence of residential segregation by race or class, furthering differences in environmental conditions due to historic and continuing processes of uneven urban development, often the result of overtly racist practices and laws. Although variation in socioeconomic and racial residential segregation in cities varies by country, and is particularly notable in the USA, residential segregation by class is on the rise in many European cities [18].

In recent years, cities have sought to improve conditions in these socioeconomically and racially segregated neighborhoods by redirecting resources to "revitalize" or "regenerate" these areas. Such renewal projects have ranged from largescale changes to environmental infrastructure and social resources to mid-and low-scale programs that address only one aspect, such as building green spaces or bringing in healthy food options through farmer's markets. Due to former and present degradation in environmental conditions and thus the relatively low valuation of land in socioeconomically and racially segregated neighborhoods, changes (i.e., renewal or improvements) to the social and physical environments of these neighborhoods have placed them at higher risk for gentrification, which in turn leads to social and cultural exclusion of long-term (i.e., legacy) underprivileged and lower-income residents, and often displacement - and ultimately to health inequities [19]. In this paper, we define gentrification, provide examples of the different gentrification processes identified in the literature, discuss its impact on health and health inequity, and present implications for both research and policy. Although these processes have implications in other contexts, we focus on cases in the Global North and particularly on cities in the USA and Europe because those are the contexts where we have conducted research and we know best.

\section{Gentrification, a (Not So New) New Form of Spatial Environmental Injustice}

Apart from the low valuation of land due to past and present degradation of environmental conditions, socioeconomically and racially segregated neighborhoods become at risk for neighborhood gentrification when they experience improvements to social and physical neighborhood environments (which may be a sign of gentrification, or may instigate it), particularly if they are also centrally located, or desirable in other ways to wealthier residents. Gentrification is defined as a process of neighborhood change through which the demographic, real estate, and business characteristics of a place reveal a transition toward a more privileged population (e.g., more educated, wealthy, whiter population), able to afford new or renovated, more expensive homes while also fomenting new cultural and consumption practices [20-22]. Although some argue that gentrification should reduce social, physical, and health inequalities due to social mixing and improvements in access to cultural and environmental resources and other services among lower-income residents remaining in their neighborhoods, past research shows that by some measures, residential socioeconomic segregation is increasing in neighborhoods experiencing gentrification [18]. Gentrification may lead to the displacement of long-termusually underprivileged - residents when they are unable to keep up with rising costs of housing and other costs of living, and it may lead to social or cultural exclusion as the population changes, shifting toward one that is wealthier, and more privileged. The increasing costs of living may be linked to heightened fear, anxiety, stress, and sleep deprivation for underprivileged residents [5]. 
Neighborhoods that are in the midst of the gentrification process often are those that receive an influx of public or private investment via new cultural and environmental amenities, new (often luxury) housing, and new forms of commerce [23]. Such changes also lead to changes in aspects of the neighborhood that influence health, but often in paradoxical ways. For instance, although new public amenities such as parks and open spaces, or private investments such as shops selling organic or other healthy foods, may indicate that the neighborhood is more supportive of better health among its residents, the equitable benefit of such amenities may be jeopardized when less wealthy, or underprivileged residents are excluded either by being displaced from their homes or excluded socioculturally, such as not being able to afford or feel welcomed, in these new amenities. All these changes in neighborhood amenities and social/cultural exclusion can be linked to feelings of socio-cultural erasure, worse nutrition habits, and decreased social cohesion for underprivileged residents [24•]. All these factors can be linked to a wide range of health outcomes, including obesity, cardiovascular diseases, poor mental health including an increased risk of depression, and suicidal thoughts for these communities [24•].

Thus, the question of how gentrification affects health becomes, more specifically, one of how gentrification affects health equity. Indeed, past research shows that gentrification itself may have no effect or even a positive effect on the health of the population as a whole while its effect on the health of underprivileged residents may be detrimental $[25 \bullet, 26 \bullet, 27 \bullet$, 28]. For instance, one study showed that while living in a gentrifying neighborhood was associated with better selfrated general health for the population at large, the opposite association was seen for Black residents [27••]. Similarly, living in a gentrified neighborhood was associated with a higher risk of pre-term delivery for Black and Hispanic women [28•], and with worse mental health among low-income children [29]. Thus, by leading to worse outcomes for underprivileged groups, gentrification may worsen existing patterns of health inequity at least partly due to the effects of uneven urban development.

\section{Future Directions-Moving Beyond a Generalist's Perspective}

To date, research on the health effects of gentrification has primarily focused broadly on neighborhood gentrification (sometimes with attention to gentrification intensity), without attention to nuances in the causes and types of gentrification which may have more specific implications for population health. In addition, research on gentrification and health has largely kept with the quantitative traditions of epidemiology research (for exceptions see [24•, 30•, 31]) and has avoided, sometimes intentionally, debates about causes of gentrification [32••]. Many researchers have suggested the need for a single measure to be used across settings and contexts for greater comparability $[18,19]$. Diverging from this generalist's strategy, although not an exhaustive list, we present below six types of gentrification (see Fig. 1) by specific driver and discuss how each may have unique implications for public health research, in addition to the general effects described above. We separate these types to highlight the specific implications of each for health inequity, despite that multiple

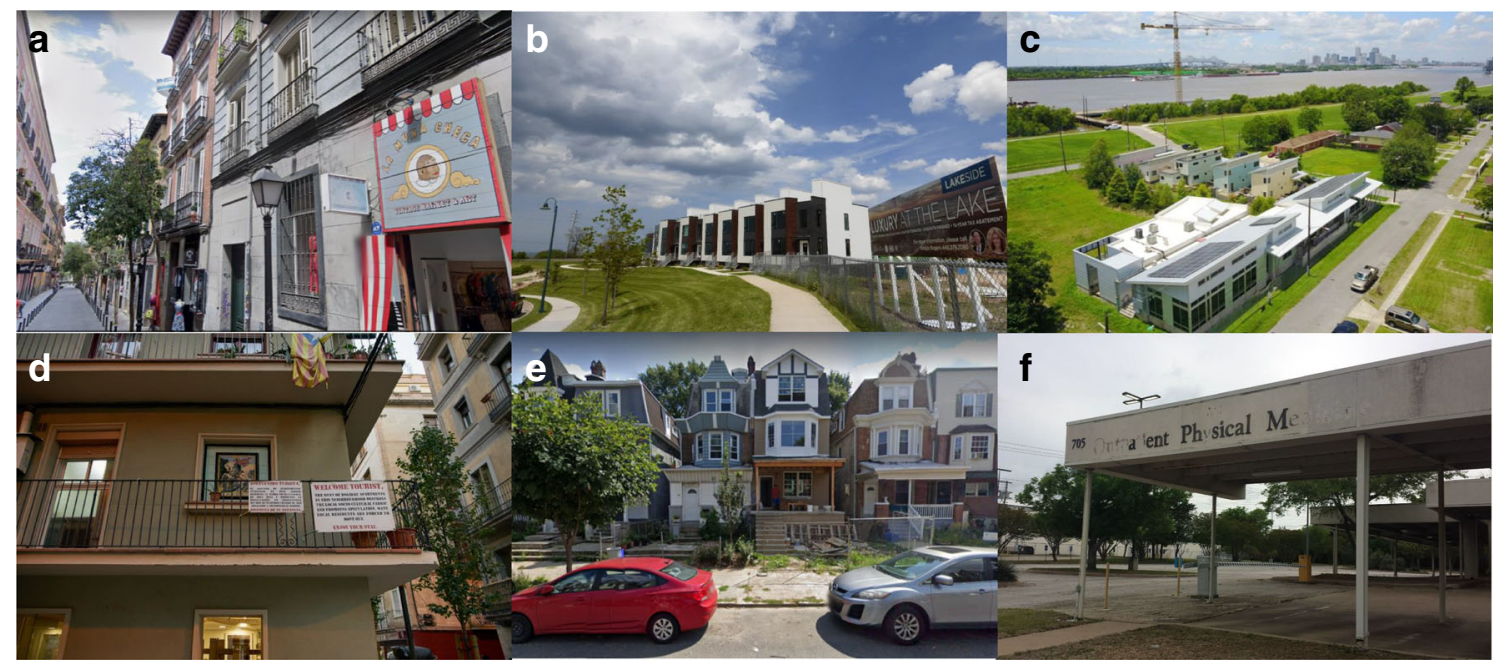

Fig. 1 Types of gentrification presented in this paper: a Street Velarde in Tribal, Madrid. A street with a high density of new trendy shops. b Battery Park luxury development in Detroit Shoreway, Cleveland. New development next, with views and with pedestrian and cycling access to Edgewater Park. c Global Green's Holy Cross community project in Lower Ninth Ward, New Orleans. New development focusing on sustainable standards available to be bought by anybody aiming to pay the price. $\mathbf{d}$ Anti-tourism and anti-gentrification banner in Barcelona. e New construction in Cedar Ave, West Philadelphia. This house, located 20min walking from University of Pennsylvania-sponsored K-8 school Sadie Tanner Mossell Alexander School, is for sale for $\$ 745000$, which represent the mean price for housing in the area. $\mathbf{f}$ Abandoned health care facility in Garland. Sources: a, c, e Google Street View. b, d, f The authors 
drivers often overlap in neighborhoods experiencing gentrification.

\section{a. Retail gentrification-Madrid (Spain)}

Changes in the retail market may come with changes in neighborhood social composition, in a process that can be defined as retail gentrification. Retail changes can be conceptualized as part of the process of gentrification or as a trigger of gentrification [33]. The type, density, and distribution of retail might be a key determinant of health and health inequities, through both positive (e.g., healthy food stores or available shops accessible by walking) and negative (e.g., tobacco retailers) changes $[34,35]$.

Madrid is one of the largest cities in Europe and has experienced an enormous increase in both population and social segregation in the last 15 years [36]. This process has been accompanied by changes in the housing market and the distribution of goods and services within the city through private investments, especially in the city center. For instance, an association of private retail investors, with the support of the city council, has dramatically transformed a deprived area (known for drug-dealing in the 80s) into an upper-middle and upper-class retail area characterized by clothing shops and renamed Triball (Triángulo Ballesta) in tribute to Manhattan's TriBeCa [23]. Throughout the city of Madrid, the distribution of walkability (including retail walking destinations) may also have increased the desirability of disadvantaged areas for retail investors due to a walkability paradox, where walkability has historically been better in socioeconomically disadvantaged neighborhoods. However, gentrification is changing the relationship between walkability and neighborhood socioeconomic status (SES) [37]. Bilal and colleagues [38•] found that gentrifying areas in Madrid have a higher baseline number of supermarkets than non-gentrifying areas. But the impacts of changes in the retail environment on health are not necessarily straight-forward. For instance, while access to healthy food via supermarkets or other healthy food outlets may be beneficial to the health of residents, in a phenomenon known as a food mirage, new and more expensive healthy food outlets might not be affordable to lower-income staying residents [39, 40]. Meanwhile, stayers might suffer a loss of social capital with the appearance of different type of stores, especially for older people [41].

b. Green gentrification-Detroit Shoreway neighborhood, Cleveland, OH (USA)

The improvement or construction of new environmental amenities such as parks, entwined with political and economic agendas, may ultimately socially and physically exclude or even displace long-term underprivileged residents, a process that has been called green or environmental gentrification [42]. Greenspace availability has been associated with a wide range of health outcomes [43-45]. Exposure to greenspaces alone has also been linked to decreased health inequalities [ 43 , 46-48]. However, when considering greenspace in relation to gentrification processes, one study shows that the benefit of living in areas with more greenspace was experienced primarily by residents of gentrifying neighborhoods with high levels of education and income [49••]. New and improved parks may be linked, for example, to increased greenspace police patrolling, changes in park uses or community erosion [31], and decreased social interactions due to forced residential displacement of long-term residents' friends and family. All these processes will also impact residents' health, in addition to the straight-forward benefit of green space, particularly harming the health of underprivileged communities that may be more dependent on their nearby built and social environment.

The Detroit Shoreway neighborhood of Cleveland, $\mathrm{OH}$, is a racially diverse neighborhood experiencing concentrated poverty and a long history of exposure to air and water pollution [50]. The most notable environmental improvement in the neighborhood has been the dramatic upgrade of Edgewater park, completed in 2013. The improvements transformed the park once riddled with crime - to one of the city's main attractions, with lakeside beaches, boat ramps, a fishing pier, picnic areas, a beach house with a bar, and programed events that attract food trucks and live performances [50]. Nowadays, new luxury housing is being built in front of Edgewater Park. These new developments use the improved environmental amenities, particularly Lake Erie and its upgraded access via Edgewater Park, as selling points, but the new housing is not affordable for long-term lower-income residents. In addition, this increased attractiveness of part of the neighborhood is impacting the housing costs of nearly the entire neighborhood and starting to force residential displacement. Thus, while the improvements to the park have led to the apparent muchneeded environmental improvement for this neighborhood, it is possible that underprivileged residents will not be able to stay long enough to benefit from the newly renovated park.

\section{c. Climate gentrification-New Orleans, LA (USA)}

The consequences of climate change are being experienced in major cities resulting in the uprooting of thousands of residents due to the damages caused by hurricanes, floods, and fires. In the process of rebuilding more climate-resistant infrastructure, property prices and new redevelopment/ regeneration projects have made it difficult for low-income residents, people of color, and migrant communities to maintain or return to their homes, which can cause a double trauma [51]. This process has been described as climate gentrification. Furthermore, climate gentrification has also been 
discussed in the context of naturally occurring protected areas of cities. For instance, low-income neighborhoods situated in higher-elevation areas within low-elevation cities like MiamiDate county in Florida are at higher risk for gentrification as investors and developers seek to make profit on these "safe zones," which could increase underprivileged residents risk of climate-related disasters such as post-traumatic stress symptoms, psychological distress, and even back and digestive problems [52-55]. Regardless of its causes, climate gentrification has resulted in attracting more privileged residents and forcing socio-demographic shifts in these areas.

In 2005, Hurricane Katrina swept through the city of New Orleans, leaving many homes inhabitable and displacing millions of residents [56]. In the months and years that followed, it became apparent that predominately lack neighborhoods had experienced greater flooding and in turn, housing damage, resulting in only $57 \%$ of the city's black population being able to return after the Hurricane $[52,57]$. Long-term residents, who left during Hurricane Katrina, found it harder to return as these neighborhoods were not prioritized by the city for restoration and rebuild, providing cheap real estate opportunities for new residents and developers. As an example, prior to Hurricane Katrina, the Lower Ninth Ward had one of the highest rates of black homeownership in the city. Post-Hurricane Katrina, it was one of the hardest hit neighborhoods with slow progress in regenerating, resulting in many displaced residents reestablishing themselves in other cities. For those that stayed, recent rezoning and new development have attracted younger white residents to the area, resulting in the gentrification of this area and the loss of $64 \%$ of its Black residents [58]. Thus, climate gentrification in cities like New Orleans illustrates the complex ways in which reoccurring and increasingly acute weather events may lead to displacement, urban renewal, inequitable recovery, and, in turn, new patterns of exposure to health risk factors as the demographic and spatial distribution of communities are shaped by this process.

\section{d. Tourism gentrification-Barcelona (Spain)}

Tourism gentrification is exemplified by urban change and neighborhood transformation according to the needs of affluent visitors characterized by the proliferation of corporate entertainment and tourism venues [59]. This type of gentrification is also characterized by the expansion of short-term accommodation, resulting in rising housing prices, changes in retail and services, the emergence of a floating population that continuously passes through and changes, and the residential displacement of long-term residents to other areas $[60,61]$. Although the exact relationship between such effects of tourism and health is still not clear, some studies have found that mass tourism harms residents' health via: environmental changes (such as disruptions in mobility, the commodification of nighttime leisure, increased insecurity, and decreased access to public space), pollution (such as air pollution), property speculation leading to eviction, a decline in social networks, and loss of identity [24•, 30•, 31, 62]. Through these pathways, the risk of stress, anxiety, depression, sleep deprivation, respiratory diseases, and poor diet may increase [24•, 30•].

For example, Barcelona is a global city undergoing acute gentrification (Montaner et al., 2013). Redevelopment trends stemming from the hosting of the Olympic Games in 1992 and the development of an urban planning scheme known as "the Barcelona model"-_including administrative support for tourism and major urban renewal projects in the 1990s and early 2000s-have contributed to a significant increase of tourism in the city in recent decades $[60,63]$. Moreover, the historical heritage, cultural dynamism, business economy, seashore including beaches (which were transformed as part of the preparation for the Olympics), and universities have contributed to the attractiveness of Barcelona [63]. Barcelona tourism has spilled over from the touristic sector itself, now affecting all sectors in the city and, consequently, all Barcelona residents [63].

\section{e. Studentification-Philadelphia, PA (USA)}

Studentification (or student-driven gentrification) can be defined as the situation where academic anchor institutions participate in the gentrification process, through direct investment procedures or changes in the housing market for students [64]. In addition to cost of living increases due to real estate investment as universities increase their footprint in specific neighborhoods, resulting demographic shifts thus include an increase in privileged young adult (college-aged) residents, leading to corresponding shifts in businesses and services to cater to this incoming population. Along with other potential effects of gentrification, studentification might make aging in place more difficult for older residents who may feel socially or culturally excluded even if they are not physically displaced [65] as such neighborhoods become increasingly youthful.

Philadelphia is one of the ten largest cities in the USA. Despite its high homeownership rate compared to other US cities and a relatively stable housing market, Philadelphia has experienced intense gentrification in recent years in some areas of the city [66]. Philadelphia is known for having several strong academic anchor institutions (e.g., University of Pennsylvania, Temple University, and Drexel University). These educational institutions are expanding their activities to participate in neighborhood revitalization processes; however, the question is how these efforts might be contributing to gentrification in these areas. For instance, since 1996, the University of Pennsylvania has been investing in the West Philadelphia Initiatives (WPI) to address safety, vacancy, 
and disinvestment concerns in West Philadelphia, where most of the University of Pennsylvania and Drexel University campuses are located [67]. Although empirical analysis has not shown gentrification in the whole neighborhood, the area served by the University of Pennsylvania-sponsored K-8 school experienced drastic demographic change among students with significantly more students from wealthy families [67], indicating potential evidence of early gentrification. There are other places where student housing has led to the displacement of underprivileged communities $[68,69]$.

\section{f. Health care gentrification-Garland, TX (USA)}

Health care gentrification is the process by which shifts in the type of and spatial distribution of health care favor wealthier residents while potentially excluding more vulnerable residents, leading to inequitable access to quality health care services. Similar to the role of academic anchoring institutions in studentification, health care systems have also become increasingly involved in redevelopment processes as for-profit real estate companies increasingly enter the health care market, both to manage health care services on a for-profit basis and for real estate investments more directly such as in the case of the former St. Joseph's Hospital in Philadelphia, now a luxury housing development. Apart from the changes within health care systems themselves, health care gentrification also refers to the new challenges that health care providers face in meeting the health care needs of patients. These include challenges treating patients who are themselves experiencing complex social environments and threats of displacement or exclusion and the challenge of providing follow-up care to patients who are physically displaced from their neighborhoods. For instance, one study showed increased hospitalization for mental health problems and use of the emergency department for mental health care among residents displaced from gentrifying neighborhoods in New York City [70].

In Garland, TX, a working-class suburb of Dallas and a city of approximately 250,000 , the city's only hospital, owned by a non-profit health care system, was closed in 2017 due to its financial failings. This forced the city of Garland - which itself largely has no control over the provision of health care since health care facilities are owned and operated by private non-profit or for-profit entities - with no viable option to improve access to care except to purchase additional ambulances to transport residents experiencing medical emergencies to the nearest hospital, now in a neighboring city. Meanwhile, new hospitals and new types of health care facilities such as urgent care clinics boasting short wait times and no appointments necessary have been opened in wealthier parts of the Dallas metropolitan area, showing that facilities are sited based on profit potential rather than health care needs. Instantiations of health care gentrification vary by type of health care system. However, maintaining equitable access to care is a challenge for all health systems, even those offering "universal" access [71], due in part to decreases in funding, and the increasing role of the private sector in health care [72-74].

\section{Challenges for Researchers}

In this review, we have unpacked how different types of gentrification may be associated with health equity. The effect of gentrification on health has been addressed in several recent systematic reviews $\left[25^{\bullet}, 26 \bullet, 75,76^{\bullet}\right]$; however, in this manuscript, we have discussed several specific changes to neighborhood environments resulting from distinct drivers of gentrification, and how those changes might be related to specific consequences for health equity. By using multiple cities as case examples, this review provides insights for policymakers to prevent unintended, detrimental consequences for health equity of urban renewal and revitalization processes.

Advancing research on the health effects of gentrification faces several challenges. Gentrification is a global process that occurs as a global neoliberal shift in urban policies toward market-based solutions of urban problems [77]. Given the global scope of gentrification processes, some researchers have advocated for global standardized measures of gentrification and its effects arguing that generalizability of results would help to find solutions and strategies that can work in different contexts [25•]. On the other hand, gentrification processes appear in specific historical, economic, socio-cultural, and urban contexts, which makes the generalizability of results at the local scale difficult. Thus, one challenge for future research is to balance the generalizability of results with detecting and understanding specific contextual effects. In fact, the definition for gentrification, and in turn the operationalization of the concept, varies across epidemiological studies to date $[25 \cdot, 78]$.

An additional challenge for future research on gentrification and health is the availability of data that includes health and demographic data, and finite geographic indicators that can link an individual to their neighborhood. Moreover, the health effects of gentrification might differ for "stayers" compared to "movers." However, to date, due in part to the difficulty on obtaining data for displaced populations, most studies on gentrification and health focus on those still living in a neighborhood, often comparing the demographic characteristics (such as race/ethnicity or income) of long-term residents to those of newer arrivals. Accordingly, in order to explore causal relationships between gentrification and health, there is a need for longitudinal data capable of follow-up for both "stayers" (both long-term residents and new arrivals) and "displaced" persons since the potential implications for health equity may be different for these distinct populations. Yet, this type of data is both costly and time consuming to collect. Furthermore, the use of census and other public use data at 
the neighborhood scale exclusively can lead to ecological fallacy and prevents us from comparing populations within a community. Finally, the methods used are determined by the quality and availability of the data.

Cities are constantly changing, both in their physical and demographic characteristics as well as the socio-spatial distribution of these. Therefore, researchers have to take into account the dynamism of cities and the challenges that this poses to scientific research on cities, gentrification, and health equity. For instance, in the current context of the COVID-19 pandemic, cities face multiple challenges such as the sustained sudden disappearance of tourism (which may be both a driver of gentrification and an important part of the local economy) or the voluntary movement of wealthier populations to second homes in less dense areas, among others, and differential impact $[79,80]$ that add uncertainty about what will happen in cities in the coming years.

\section{Conclusions}

Changes in social and physical environments of socioeconomically and racially segregated neighborhoods place these neighborhoods at higher risk of gentrification and its impacts on health equity (including fear, anxiety, stress, sleep deprivation, worse nutrition habits, lower social cohesion, obesity, cardiovascular diseases or mental health, all of which affect different segments of the population with greater intensity, for example). The strength of the association with these health outcomes and the importance of other potential pathways and health impacts will largely depend on the specific drivers of gentrification in a given neighborhood or city.

Gentrification is increasingly impacting neighborhoods around the globe. Thus, exploring how different population groups and types of gentrification - such as retail, green/environmental, climate, tourism, studentification, or health caremay lead to differential health effects is emerging as paramount to fully understand the impacts of gentrification on public health. However, developing appropriate tools, definitions, and measurements and accessing data at an suitable geographic scale remain as methodological challenges for the research on gentrification and health to be translated into policy.

Funding Helen Cole and Margarita Triguero-Mas received funding from the European Research Council (ERC) under the European Union's Horizon 2020 research and innovation program (grant agreement No. 678034; PI Isabelle Anguelovski) and from the Juan de la Cierva fellowship program of the Spanish Ministry of Economy and Competitiveness (FJCI-2017-33842 and IJC-2018-035322-I). Pedro Gullón was supported by the European Union's Horizon 2020 research and innovation program under the Marie Skłodowska-Curie grant agreement No 842957.

\section{Declarations}

Conflict of Interest The authors declare no competing interests.

Human and Animal Rights and Informed Consent This article does not contain any studies with human or animal subjects performed by any of the authors.

\section{References}

Papers of particular interest, published recently, have been highlighted as:

- Of importance

•• Of major importance

1. Marmot M. Society and the slow burn of inequality. Lancet. 2020;395:1413-4. https://doi.org/10.1016/S0140-6736(20)309405.

2. Braveman PA, Kumanyika S, Fielding J, LaVeist T, Borrell LN, Manderscheid R, et al. Health disparities and health equity: the issue is justice. Am J Public Health. 2011;101:S149-55. https:// doi.org/10.2105/AJPH.2010.300062.

3. Gee GC, Ford CL. Structural racism and health inequities: old issues, new directions. Du Bois Rev. 2011;8:115-32. https://doi.org/ 10.1017/S1742058X11000130.

4. LaVeist TA. Segregation, poverty, and empowerment: health consequences for African Americans. Milbank Q. 1993;71:41-64. https://doi.org/10.2307/3350274.

5. Krieger N. Discrimination and health inequities. Int J Health Serv. 2014;44:643-710. https://doi.org/10.2190/HS.44.4.b.

6. Bailey ZD, Krieger N, Agénor M, Graves J, Linos N, Bassett MT. Structural racism and health inequities in the USA: evidence and interventions. Lancet. 2017;389:1453-63. https://doi.org/10.1016/ S0140-6736(17)30569-X.

7. Kershaw KN, Albrecht SS, Carnethon MR. Racial and ethnic residential segregation, the neighborhood socioeconomic environment, and obesity among Blacks and Mexican Americans. Am J Epidemiol. 2013;177:299-309. https://doi.org/10.1093/aje/ kws372.

8. Dai D. Black residential segregation, disparities in spatial access to health care facilities, and late-stage breast cancer diagnosis in metropolitan Detroit. Health Place. 2010;16:1038-52. https://doi.org/ 10.1016/j.healthplace.2010.06.012.

9. Williams DR, Sternthal M, Wright RJ. Social determinants: taking the social context of asthma seriously. Pediatrics. 2009;123:S174 84. https://doi.org/10.1542/peds.2008-2233H.

10. Collins CA, Williams DR. Segregation and mortality: the deadly effects of racism? Sociol Forum. 1999;14:495-523. https://doi.org/ 10.1023/A:1021403820451.

11. Taylor HL, Hill W. Historical roots of the urban crisis: African Americans in the industrial city, 1900-1950; 2013. https://doi.org/ $10.4324 / 9781315052106$.

12. Brulle RJ, Pellow DN. Environmental justice: human health and environmental inequalities. Annu Rev Public Health. 2006;27: 103-24. https://doi.org/10.1146/annurev.publhealth.27.021405. 102124.

13. Wing S, Fruin S, Ritz B. Preterm birth among infants exposed to in utero ultrafine particle emissions from aircraft engines near the Los Angeles International Airport. ISEE Conf Abstr. 2018;2018. https:// doi.org/10.1289/isesisee.2018.o02.03.51. 
14. Chaparro MP, Benzeval M, Richardson E, Mitchell R. Neighborhood deprivation and biomarkers of health in Britain: the mediating role of the physical environment. BMC Public Health. 2018;18:801. https://doi.org/10.1186/s12889-018-5667-3.

15. Chakraborty J. Cancer risk from exposure to hazardous air pollutants: spatial and social inequities in Tampa Bay, Florida. Int $J$ Environ Health Res. 2012;22:165-83. https://doi.org/10.1080/ 09603123.2011 .628643$.

16. Brender JD, Maantay JA, Chakraborty J. Residential proximity to environmental hazards and adverse health outcomes. Am J Public Health. 2011;101:S37-52. https://doi.org/10.2105/AJPH.2011. 300183.

17. Krieger N. Living and dying at the crossroads: racism, embodiment, and why theory is essential for a public health of consequence. Am J Public Health. 2016;106:832-3. https://doi.org/10.2105/AJPH. 2016.303100.

18. Musterd S, Marcińczak S, van Ham M, Tammaru T. Socioeconomic segregation in European capital cities. Increasing separation between poor and rich. Urban Geogr. 2017;38:106283. https://doi.org/10.1080/02723638.2016.1228371.

19. Mehdipanah R, Manzano A, Borrell C, Malmusi D, RodriguezSanz M, Greenhalgh J, et al. Exploring complex causal pathways between urban renewal, health and health inequality using a theorydriven realist approach. Soc Sci Med. 2015;124:266-74. https://doi. org/10.1016/j.socscimed.2014.11.050.

20. Smith N. The new urban frontier: gentrification and the revanchist city. Oxon: : Routledge 1996.

21. Lees L, Shin HB, Lopez-Morales E. Global gentrifications: uneven development and displacement. Policy Press. 2015.

22. Smith N. Gentrification and uneven development. Econ Geogr. 1982;58:139-55.

23. Sequera J, Janoschka M. Gentrification dispositifs in the historic centre of Madrid: a re-consideration of urban governmentality and state-led urban reconfiguration. - Michael Janoschka. In: Lees L, Shin HB, Lopez-Morales E, eds. Global gentrifications: uneven development and displacement. London: : Polity Press 2015. 37594.http://www.michael-janoschka.de/gentrification-dispositifs-inthe-historic-centre-of-madrid-a-re-consideration-of-urbangovernmentality-and-state-led-urban-reconfiguration/ ().

24. Anguelovski, I.; Triguero-Mas, M.; Connolly, J.J.T.; Kotsila, P.; Shokry, G.; Pérez Del Pulgar, C.; Garcia-Lamarca M, et al.. Gentrification and health in two global cities: a call to identify impacts for socially-vulnerable residents. Cities Heal 2019;:1-10. Presents the hypothesize pathways by which gentrification affects health.

25. Bhavsar NA, Kumar M, Richman L. Defining gentrification for epidemiologic research: a systematic review. PLoS One. 2020;15: e0233361. https://doi.org/10.1371/journal.pone.0233361 Presents a basic conceptual model for understanding the relationship between gentrification and health.

26. Tulier ME, Reid C, Mujahid MS, et al. Clear action requires clear thinking': a systematic review of gentrification and health research in the United States. Health Place. 2019;59:102173. https://doi.org/ 10.1016/j.healthplace.2019.102173 Robust systematic review of literature on the relationship between gentrification and health.

27.• Gibbons J, Barton MS. The association of minority self-rated health with Black versus White gentrification. J Urban Health. 2016;93: 909-22 Demonstrates the role of race in differentiating the impact of gentrification on self-rated health using a robust dataset.

28. Huynh M, Maroko AR. Gentrification and preterm birth in New York City, 2008-2010. J Urban Health. 2013;91:211-20.

29. Dragan KL, Ellen IG, Glied SA. Gentrification and the health of low-income children in New York City. Health Aff. 2019;38:142532.

30. Sánchez-Ledesma E, Vásquez-Vera H, Sagarra N, et al. Perceived pathways between tourism gentrification and health: a participatory
Photovoice study in the Gòtic neighborhood in Barcelona. Soc Sci Med. 2020;258:113095. https://doi.org/10.1016/j.socscimed.2020. 113095 Exemplifies the use of non-quantitative methods to illuminate pathways connecting gentrification and health.

31. Oscilowicz E, Honey-Rosés J, Anguelovski I, Triguero-Mas M, Cole H. Young families and children in gentrifying neighbourhoods: how gentrification reshapes use and perception of green play spaces. Local Environ. 2020;25:765-86. https://doi. org/10.1080/13549839.2020.1835849.

$32 . \cdots$ Cole HVS. A call to engage: considering the role of gentrification in public health research. Cities Heal 2020;:1-10. doi:https://doi.org/ 10.1080/23748834.2020.1760075. Describes how key debates around the concept of gentrification can be integrated into epidemiologic study design decisions.

33. Hubbard P, Hubbard P. Introduction: gentrification and retail change. In: The battle for the high street. Palgrave Macmillan UK. 2017:1-13. https://doi.org/10.1057/978-1-137-52153-8_1.

34. Young-Wolff KC, Henriksen L, Delucchi K, Prochaska JJ. Tobacco retailer proximity and density and nicotine dependence among smokers with serious mental illness. Am J Public Health. 2014;104:1454-63. https://doi.org/10.2105/AJPH.2014.301917.

35. Smith M, Hosking J, Woodward A, Witten K, MacMillan A, Field A, et al. Systematic literature review of built environment effects on physical activity and active transport - an update and new findings on health equity. Int J Behav Nutr Phys Act. 2017;14:158. https:// doi.org/10.1186/s12966-017-0613-9.

36. Sorando D, Leal J. Economic crisis, social change and segregation processes in Madrid. In: Tammaru T, Ham M van, Marcińczak S, et al., eds. Socio-economic segregation in European capital cities: east meets west. Routledge 2015. 238-61. doi:https://doi.org/10. 4324/9781315758879-17

37. Gullón P, Bilal U, Cebrecos A, Badland HM, Galán I, Franco M. Intersection of neighborhood dynamics and socioeconomic status in small-area walkability: the Heart Healthy Hoods project. Int $J$ Health Geogr. 2017;16:21. https://doi.org/10.1186/s12942-0170095-7.

38. Bilal U, Jones-Smith J, Diez J, et al. Neighborhood social and economic change and retail food environment change in Madrid (Spain): the Heart Healthy Hoods study. Health Place. 2018;51: 107-17. https://doi.org/10.1016/j.healthplace.2018.03.004 Describes how retail environments are shaped and can be related to public health in Madrid.

39. Caspi CE, Sorensen G, Subramanian SV, Kawachi I. The local food environment and diet: a systematic review. Health Place. 2012;18: 1172-87. https://doi.org/10.1016/j.healthplace.2012.05.006.

40. Anguelovski I. Healthy food stores, greenlining and food gentrification: contesting new forms of privilege, displacement and locally unwanted land uses in racially mixed neighborhoods. Int J Urban Reg Res. 2015;39:1209-30. https://doi.org/10.1111/1468-2427. 12299.

41. Conde P, Gutiérrez M, Sandín M, Díez J, Borrell L, Rivera-Navarro $\mathrm{J}$, et al. Changing neighborhoods and residents' health perceptions: the heart healthy hoods qualitative study. Int J Environ Res Public Health. 2018;15:1617. https://doi.org/10.3390/ijerph15081617.

42. Gould KA, Lewis TL. Green gentrification : urban sustainability and the struggle for environmental justice. New York, NY: : Routledge 2017.

43. Triguero-Mas M, Donaire-Gonzalez D, Seto E, Valentín A, Martínez D, Smith G, et al. Natural outdoor environments and mental health: stress as a possible mechanism. Environ Res. 2017;159:629-38. https://doi.org/10.1016/j.envres.2017.08.048.

44. O'Callaghan-Gordo C, Kogevinas M, Cirach M, et al. Residential proximity to green spaces and breast cancer risk: the multicasecontrol study in Spain (MCC-Spain). Int J Hyg Environ Health. 2018;221:1097-106. https://doi.org/10.1016/j.ijheh.2018.07.014. 
45. Chen H, Burnett RT, Bai L, Kwong JC, Crouse DL, Lavigne E, et al. Residential greenness and cardiovascular disease incidence, readmission, and mortality. Environ Health Perspect. 2020;128: 087005. https://doi.org/10.1289/EHP6161.

46. Kabisch N, Korn H, Stadler J, et al. Nature-based solutions to climate change adaptation in urban areas - linkages between science, policy and practice. 2017. 1-11. doi:https://doi.org/10.1007/ 978-3-319-56091-5 1

47. Mitchell RJ, Richardson EA, Shortt NK, Pearce JR. Neighborhood environments and socioeconomic inequalities in mental well-being. Am J Prev Med. 2015;49:80-4. https://doi.org/10.1016/j.amepre. 2015.01.017.

48. Pearce J, Cherrie M, Shortt N, Deary I, Ward Thompson C. Life course of place: a longitudinal study of mental health and place. Trans Inst Br Geogr. 2018;43:555-72. https://doi.org/10.1111/tran. 12246.

49.• Cole HVS, Triguero-Mas M, Connolly JJT, et al. Determining the health benefits of green space: does gentrification matter? Health Place. 2019;57:1-11. https://doi.org/10.1016/j.healthplace.2019. 02.001 First study to quantitatively study gentrification as a mediating factor in the relationship between the green space and health.

50. Berry DK, Coffman KB, Zimmerman BM. Cleveland Metroparks and the Lake Erie Coast: natural capital and resilience in the Forest City. In: Rodriguez GR, Brebbia CA, Almorza D, eds. Transactions on the built environment. Boston: : WIT Press 2017. 23-32.

51. Anguelovski I, Connolly JJT, Pearsall H, Shokry G, Checker M, Maantay J, et al. Why green 'climate gentrification' threatens poor and vulnerable populations. Proc Natl Acad Sci U S A. 2019;116: 26139-43. https://doi.org/10.1073/pnas.1920490117.

52. Aune KT, Gesch D, Smith GS. A spatial analysis of climate gentrification in Orleans Parish, Louisiana post-Hurricane Katrina. Environ Res. 2020;185:109384. https://doi.org/10.1016/j.envres. 2020.109384.

53. Lowe SR, Raker EJ, Arcaya MC, Zacher ML, Waters MC, Rhodes JE. A life-course model of trauma exposure and mental health among low-income survivors of Hurricane Katrina. J Trauma Stress. 2020;33:950-61. https://doi.org/10.1002/jts.22581.

54. Zacher M, Raker EJ, Arcaya MC, et al. Physical health symptoms and Hurricane Katrina: individual trajectories of development and recovery more than a decade after the storm. Am J Public Health 2020;:e1-8. doi:https://doi.org/10.2105/ajph.2020.305955

55. Keenan JM, Hill T, Gumber A. Climate gentrification: from theory to empiricism in Miami-Dade County. Florida Environ Res Lett. 2018;13:054001. https://doi.org/10.1088/1748-9326/aabb32.

56. Brunkard J, Namulanda G, Ratard R. Hurricane katrina deaths, Louisiana, 2005. Disaster Med Public Health Prep. 2008;2:21523. https://doi.org/10.1097/DMP.0b013e31818aaf55.

57. Fussell E, Sastry N, Vanlandingham M. Race, socioeconomic status, and return migration to New Orleans after Hurricane Katrina. Popul Environ. 2010;31:20-42. https://doi.org/10.1007/s11111009-0092-2.

58. Moskowitz P. New Orleans' Lower Ninth Ward targeted for gentrification: 'it's going to feel like it belongs to the rich' | New Orleans | The Guardian. Guard. 2015; https://www.theguardian. com/us-news/2015/jan/23/new-orleans-lower-ninth-ward-condosgentrification (

59. Gotham KF. Tourism gentrification: the case of New Orleans' Vieux Carre (French Quarter). Urban Stud. 2005;42:1099-121. https://doi.org/10.1080/00420980500120881.

60. Degen M, García M. The transformation of the 'Barcelona Model': an analysis of culture, urban regeneration and governance. Int $J$ Urban Reg Res. 2012;36:1022-38. https://doi.org/10.1111/j.14682427.2012.01152.x.
61. Cocola-Gant A. Tourism gentrification. In: Handbook of gentrification studies. Edward Elgar Publishing Ltd. 2018. 281-93. doi: https://doi.org/10.4337/9781785361746.00028

62. Nofre J, Sánchez-Fuarros Í, Carlos Martins J, et al. Exploring nightlife and urban change in Bairro Alto, Lisbon. City Community. 2017;16:330-44. https://doi.org/10.1111/cico.12248.

63. López PF. Barcelona, from a city with tourism to a tourist city. Notes on a complex and unfinished process. Doc d'Analisi Geogr. 2015;61:483-506. https://doi.org/10.5565/rev/dag.296.

64. Moos M, Revington N, Wilkin T, Andrey J. The knowledge economy city: gentrification, studentification and youthification, and their connections to universities. Urban Stud. 2019;56:1075-92. https://doi.org/10.1177/0042098017745235.

65. Powell KH. A new neighborhood every fall: aging in place in a College Town. J Gerontol Soc Work. 2016;59:537-53. https://doi. org/10.1080/01634372.2016.1256363.

66. Ding L, Hwang J, Divringi E. Gentrification and residential mobility in Philadelphia. Reg Sci Urban Econ. 2016;61:38-51. https:// doi.org/10.1016/j.regsciurbeco.2016.09.004.

67. Ehlenz MM. Neighborhood Revitalization and the anchor institution. Urban Aff Rev. 2016;52:714-50. https://doi.org/10.1177/ 1078087415601220.

68. Pickren G. Where can i build my student housing? The politics of studentification in Athens-Clarke County, Georgia. Southeast Geogr. 2012;52:113-30. https://doi.org/10.1353/sgo.2012.0019.

69. Dobbs OM. Investigating the housing market for student tenants surrounding an urban university. 2013.https://digitalcommons. wayne.edu/honorstheses/14 ().

70. Lim S, Chan PY, Walters S, Culp G, Huynh M, Gould LH. Impact of residential displacement on healthcare access and mental health among original residents of gentrifying neighborhoods in New York City. PLoS One. 2017;12:e190139.

71. Dahrouge S, Hogg W, Muggah E, Schrecker T. Equity of primary care service delivery for low income "sicker" adults across 10 OECD countries. Int $J$ Equity Health. 2018;17:182. https://doi. org/10.1186/s12939-018-0892-z.

72. Sumah AM, Baatiema L, Abimbola S. The impacts of decentralisation on health-related equity: a systematic review of the evidence. Health Policy (New. York). 2016;120:1183-92. https://doi.org/10. 1016/j.healthpol.2016.09.003.

73. Blanchet Garneau A, Browne AJ, Varcoe C. Understanding competing discourses as a basis for promoting equity in primary health care. BMC Health Serv Res. 2019;19:764. https://doi.org/10.1186/ s12913-019-4602-3.

74. Martinez A, Smith K, Llop-Gironés A, et al. La mercantilización de la sanidad: El caso de Catalunya. Cuad Relac Laborales. 2016;34: 335-55. https://doi.org/10.5209/CRLA.53460.

75. Smith GS, Breakstone H, Dean LT, Thorpe RJ Jr. Impacts of gentrification on health in the US: a systematic review of the literature. J Urban Health. 2020;97:845-56. https://doi.org/10.1007/s11524020-00448-4.

76. Schnake-Mahl AS, Jahn JL, Subramanian SV, et al. Gentrification, neighborhood change, and population health: a systematic review. $J$ Urban Health. 2020;97:1-25. https://doi.org/10.1007/s11524-01900400-1 Robust systematic review on the relationship between gentrification and health.

77. Smith N. New globalism, new urbanism: gentrification as global urban strategy. Antipode. 2002;34:427-50. https://doi.org/10.1111/ 1467-8330.00249.

78. Firth CL, Fuller D, Wasfi R, et al. Causally speaking: challenges in measuring gentrification for population health research in the United States and Canada. Heal Place 2020;63. doi:https://doi. org/10.1016/j.healthplace.2020.102350. Analyzes why measurement variation and methods are important considerations for public health research about gentrification. 
79. Sharifi A, Khavarian-Garmsir AR. The COVID-19 pandemic: impacts on cities and major lessons for urban planning, design, and management. Sci Total Environ. 2020;749:142391. https://doi.org/ 10.1016/j.scitotenv.2020.142391.

80. Cole HVS, Anguelovski I, Baró F, García-Lamarca M, Kotsila P, Pérez del Pulgar C, et al. The COVID-19 pandemic: power and privilege, gentrification, and urban environmental justice in the global north. Cities Heal. 2020;00:1-5. https://doi.org/10.1080/ 23748834.2020.1785176.

Publisher's Note Springer Nature remains neutral with regard to jurisdictional claims in published maps and institutional affiliations. 